\title{
ADOPTION OF E-COMMERCE IN SMES: LESSONS FROM STAGE MODELS
}

\author{
ADA SCUPOLA \\ Department of Social Sciences, Roskilde University, Denmark
}

\begin{abstract}
The paper presents the results of an exploratory case study of early adopters of electronic commerce. The data have been analyzed by applying PriceWaterhouseCoopers stage model of adoption of e-commerce. This model has been used because it takes into consideration many factors such as adoption benefits and barriers, uses, evolution of e-commerce capabilities, and the measures that should be taken to increase adoption and diffusion of ecommerce in SMEs. The paper concludes that this model, while having many strengths, presents also some limitations, the most important being not taking into consideration the changes in the company capabilities and business processes that have to take place in order to go from one level to the next of ecommerce capabilities.
\end{abstract}

\section{INTRODUCTION}

It is believed that e-commerce could contribute to increase the market power and competitiveness of small and medium size enterprises (OECD, 1999). We adopt Zwass (1997) definition of e-commerce (here also called Internet commerce) as "the sharing of business information, maintaining business relationships, and conducting business transactions by means of telecommunications networks" and the European Parliament definition of SMEs according to which they are businesses with up to 500 employees (OECD, 1999). Furthermore, we focus on the business-to-business ecommerce conducted over Internet.

E-commerce is not, however, risk free for small companies as they often lack the resources, knowledge and understanding to take full advantage

The original version of this chapter was revised: The copyright line was incorrect. This has been corrected. The Erratum to this chapter is available at DOI: 10.1007/978-0-387-35692-1_36 
of these technologies. Therefore the need to better understand the process of e-commerce adoption and diffusion among SMEs. The question that this article addresses is: What are the stages through which e-commerce adoption unfolds and what are the characteristics of these stages?

Zaltman et al. (1973) found that within organizations the innovation process occurs in 2 stages. The first is a firm level decision to adopt the innovation called primary adoption. The second is the actual implementation including individual adoption by users, also called secondary adoption. However, even when the primary adoption decision has occurred, this is not a guarantee that the innovation will actually be implemented or used by the targeted users, as often there might be an assimilation gap (Gallivan, 2001). In explaining the adoption and diffusion of innovations, different types of models can be used such as "process models" and variance models. The stage models (which can be considered a sub group of process models) are based on the premise that the elements in the system move through a pattern of distinct stages over a period of time and that these stages can be described. According to Nolan (1973) two key characteristics of stage theory formulation are 1) the identification of elements and 2) the conception of their growth through time. The concept of an element is that it is generic to a particular field and that it can be specified by a set of attributes. The concept of growth over a period of time implies that the elements change as attributes expand or contract in number and nature. Well-known stage models in the diffusion of innovation theory are the ones developed by Nolan (1973), Prescott and Conger (1995) and Rogers (1995). However while these models focus on the adoption, implementation and diffusion of innovations in general and information technology in particular, very few stage models address the adoption, implementation and diffusion of Internet technology and e-commerce in particular. The characteristics of e-commerce and its evolution being different from the ones of other IT systems as Internet-commerce is based on complex, networked technologies that provide a seamless unified user interface to information systems within and outside the organization (Damsgaard and Scheepers, 1999).

The article is structured as follows. The following section is a review of the stage models of e-commerce adoption. The third section describes the research design and the data collection, while section four describes the case companies. Finally section 5 presents a summary of the results, while section 6 gives a short discussion and suggestions for further research. 


\section{REVIEW OF STAGE MODELS OF E- COMMERCE ADOPTION}

The research on stage models adoption of e-commerce is mainly summarized in five studies (Table 1). Two studies, Quelch and Klein (1996) and Bickerton, Bickerton and Simpson-Holley (1999) provide general models of site development. Poon and Swatman (1999), Grant (1999) and PriceWaterhouseCoopers (1999) present stage models specific to SMEs.

Quelch and Klein's (1996) model consists of two evolutionary paths for web site development and therefore e-commerce adoption. These paths are different depending upon whether an organization is an already existing company or a start-up company with the purpose of doing business only on the Internet. The already existing company would be interested mainly in addressing the needs of existing customers and promoting and selling existing products. This company would follow the 'information-totransaction model', consisting of the following sequential steps:

1. Promote brand image/ Provide product information.

2. Collect information about customers/ Perform market research.

3. Provide customer support and service.

4. Develop internal support and service.

5. Provide online transactions.

Examples of companies using this model are Federal Express and 3M. For a start-up company with the purpose of selling products through Internet, a 'transaction-to-information' model would typically be more suitable in order to build brand image, provide product support and win repeat purchases. Examples of companies following this model are Software.Net and CDNow. This model of site development consists of the following stages:

1. Provide online transactions.

2. Provide customer support and service.

3. Promote brand image/ Provide product information.

4. Collect information about customers/ Perform market research. 


\begin{tabular}{|l|l|l|l|}
\hline Model & Number of Stages & $\begin{array}{l}\text { Focus of the } \\
\text { model }\end{array}$ & Type of company \\
\hline $\begin{array}{l}\text { Quelch and Klein } \\
\text { (1996) }\end{array}$ & $\begin{array}{l}\text { Already existent } \\
\text { company: 5 stages } \\
\text { Internet-based only } \\
\text { company: 4 stages }\end{array}$ & $\begin{array}{l}\text { Web Site } \\
\text { Development }\end{array}$ & $\begin{array}{l}\text { Distinguishes between } \\
\text { the already existent } \\
\text { company and Internet- } \\
\text { based only company }\end{array}$ \\
\hline $\begin{array}{l}\text { Bickerton et al. } \\
(1999)\end{array}$ & 3 & $\begin{array}{l}\text { Internet } \\
\text { Technology } \\
\text { Development }\end{array}$ & Any type of company \\
\hline $\begin{array}{l}\text { Poon and } \\
\text { Swatman (1999) }\end{array}$ & 3 & $\begin{array}{l}\text { Level of internal - } \\
\text { external integration }\end{array}$ & SMEs \\
\hline $\begin{array}{l}\text { Grant (1999) } \\
\text { Company } \\
\text { capabilities, mainly } \\
\text { internal to the } \\
\text { corporation }\end{array}$ & SMEs \\
\hline $\begin{array}{l}\text { PriceWaterhouse } \\
\text { Coopers (1999) }\end{array}$ & 5 & $\begin{array}{l}\text { E-commerce } \\
\text { capabilities, takes } \\
\text { into consideration } \\
\text { external and } \\
\text { internal factors }\end{array}$ & SMEs \\
\hline
\end{tabular}

Table 1. Overview of Stage Models of E-commerce Adoption in SMEs

Bickerton et al. (1999) has also developed a model of Internet technology development, based on 3 stages summarized below:

1. Internet presentation. In this stage the company chooses to publish information on the Web that can only be viewed trough the web browser. This stage is used to provide an image, to impart knowledge and values about the company, as well as to give access to information and to illustrate products or services.

2. Internet interaction. This stage allows for two-way communication between an organization and its customers. The system asks questions and the user supplies answers. At this stage, Internet technology becomes more then a purely electronic publishing tool.

3. Internet representation. In this stage the organization uses Internet technology to reorganize some of its business processes online. The technology executes a business process otherwise done by a person. This could be any activity as for example producing a new sales channel.

Poon and Swatman (1999) develop a stage model of e-commerce adoption mainly focusing on the level of integration between the internal company applications and Internet. This model suggests that integration will gradually increase as SMEs understand the potential benefits of e-commerce and that there will be no integration until a small enterprise sees these benefits. This is mainly due to the fact that the organizational processes have to be re-organized as a consequence of full integration. The model starts 
with minimum Internet-to-internal application integration, to limited Internet-to-internal integration to full Internet-to-internal application integration. The sequential steps are summarized below:

1. Purely inter-organizational exploitation

2. Selective local integration

3. Full local integration

Grant's (1999) model of e-commerce adoption among SMEs focuses on the competencies required for the transformation of a traditional business to an electronic business. It consists of five stages:

1. Immaturity: the company is not ready yet to start e-business;

2. On the Internet: the company reaches a stage of basic awareness;

3. E-commerce provisional strategy decided: a specific awareness to the business is reached and a plan is made to adopt e-commerce;

4. Ready to implement: the obstacles for the implementation are overcome, and finally

5. Implementation.

PriceWaterhouseCoopers (1999) also develops a five-stage model of SMEs e-commerce adoption based on the Internet capabilities a company has. They describe the steps as follows:

1. The cycle begins with the perception by SMEs of the opportunities and benefits offered by e commerce, such as greater access to international markets.

2. Based on their perceptions of opportunities and benefits, SMEs develop e-commerce capabilities.

3. As SMEs attempt to use the developed e-commerce capabilities, they experience a number of inhibitors to realizing their potential. The perception of these inhibitors may lead SMEs to develop less ecommerce capability than they might have done based solely on an assessment of opportunities and benefits. Inhibitors could include poor telecommunication infrastructure or gaps in the e-commerce capabilities of business partners.

4. The experiences or perceptions SMEs have with respect to opportunities and inhibitors influence what measures they believe should be taken by governments or other stakeholders to facilitate e-commerce adoption.

5. Previous stages in the cycle lead to the enabled benefits that SMEs actually experience. These experiences, in turn, influence their perception of the potential opportunities and benefits of e-commerce and contribute to another cycle of e-commerce development. (PriceWaterhouseCoopers, 1999, p. 8) 


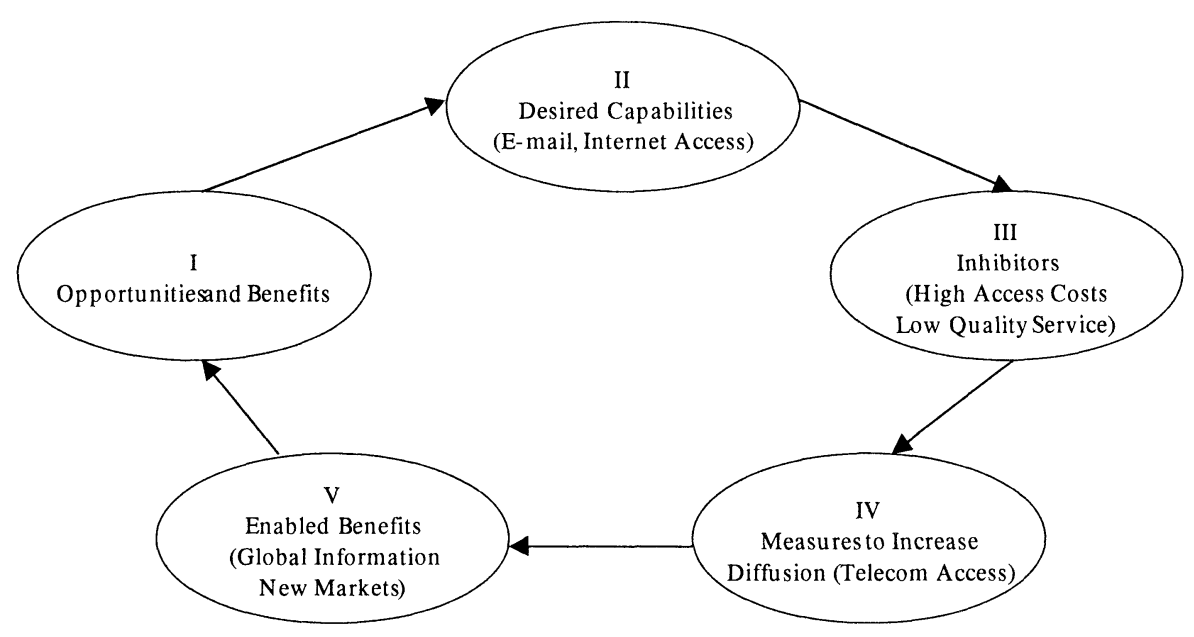

Figure 1. A Stage Model of SME's Adoption of B-to-B E-commerce

PriceWaterhouseCoopers, 1999

PriceWaterhouseCoopers distinguishes four levels of capabilities. Level 1 represents SMEs with very basic or no online capabilities, level 2 represents SMEs with a Web site, but no advanced capabilities, level 3 includes SMEs that are able to take orders and provide customer service on their web site, while level 4 represents SMEs that can make complete transactions and receive payment on their web site.

We can see that while Quelch and Klein (1996) and Bickerton et al. (1999) models focus on the web site characteristics and Poon and Swatman's model focuses mainly on the level of internal-external processes integration, Grant (1996) and PriceWaterhouseCoopers (1999) models are more comprehensive since they also take into consideration other factors such as capabilities. Furthermore, while Grant (1999) mainly focuses on the capabilities internal to the organization, PriceWaterhouseCoopers also take into consideration factors external to the organization such as government intervention, which is the reason why I choose this model to structure the analysis. 


\section{RESEARCH DESIGN AND DATA COLLECTION}

I used exploratory case studies (Yin, 1994) of five SMEs in Southern Italy to understand the specific characteristics of the different stages through which the adoption and diffusion of e-commerce takes place. The companies, belonging to different sectors, have been chosen on the basis of representativeness and accessibility following the criteria of having had an Internet-connection for a period of at least 3 years and having a maximum of 500 employees. The data were collected with semi-structured interviews. In all the cases the person interviewed has been the owner also functioning as the CEO. The person to be interviewed had been suggested by the companies themselves after a first telephone contact.

The interviews have been conducted personally in spring 2001 and have lasted between 1.5 and 3 hours each. In addition the company's home page (when existing) has been visited. Each interview was transcribed and the data analyzed by keeping in mind the elements of the stage model.

\section{COMPANIES DESCRIPTION}

In this section, I describe the case companies, summarized in table 2, according to PriceWaterhouseCoopers model. In the discussion I put together stage I and II, and don't take into consideration stage $\mathrm{V}$, since this is partially the same as stage I.

\begin{tabular}{|l|l|l|l|}
\hline $\begin{array}{l}\text { Company } \\
\text { Number }\end{array}$ & Type of Business & No. Of Employees & Capabilities Level \\
\hline F1 & IT Consultants & 80 & $\begin{array}{l}\text { Level 2: Simple Home } \\
\text { page and permanent } \\
\text { Internet connection }\end{array}$ \\
\hline F2 & Distributor & 15 & $\begin{array}{l}\text { Level 3: Home Page and } \\
\text { Online Selling Catalog }\end{array}$ \\
\hline F3 & $\begin{array}{l}\text { Intermediary in the textile } \\
\text { business }\end{array}$ & 2 (Family Driven) & $\begin{array}{l}\text { Level 1: Internet } \\
\text { Connection, No Web Site }\end{array}$ \\
\hline F4 & $\begin{array}{l}\text { Production and } \\
\text { commercialization of } \\
\text { textiles }\end{array}$ & 300 & $\begin{array}{l}\text { Level 2: Home page } \\
\text { internal-external } \\
\text { integration }\end{array}$ \\
\hline F5 & $\begin{array}{l}\text { Distributor } \\
\text { Level 2: Home Page and } \\
\text { Permanent Internet } \\
\text { Connection }\end{array}$ \\
\hline
\end{tabular}

Table 2. Companies Overview 


\subsection{Description of F1}

F1 is a software house, offering consulting services to government, service sector and SMEs, with 80 employees. Recently they have started implementing business-to-business e-commerce for client companies.

\subsubsection{Stage I and II}

The CEO/owner recalls how when the Internet first came he was struggling to understand how they could use it and for what purpose. It was clear to him that there was much potential in this technology, but he did not know how to leverage it. He started therefore slowly building some capabilities in-house to leverage Internet technologies for consulting purposes. He decided for example to be an Internet provider, to hire consultants with web related experiences, to have an Internet connection, to have a web site, etc. Presently, F1 is at capabilities' level 2.

\subsubsection{Stage III}

It has not been easy for F1 to sell Internet related consulting services in the past and presently. This is mainly due to the fact that companies in other sectors according to F1 are still at the level of using computer systems for basic purposes such as accounting, word processing, etc. Some companies have a local area network, but very few understand the power of Internet technology. Therefore lack of knowledge and awareness have been the major barriers for F1 to sell its consulting services to local SMEs. They also admit that another major barrier is their (the consultants) inability to explain the potential of the technology to their customers in a simple way. Therefore for many years, even though they had developed basic web applications such as Home Pages and online catalogs, it was hard for them to sell these services, thus relatively been prevented from further developing human and Internet related capabilities.

\subsubsection{Stage IV}

As a result of their experience, they strongly believe that government intervention in terms of informational campaigns to increase awareness, tax incentives, etc. could be a viable way to increase the diffusion of ecommerce in SMEs. 


\subsection{Description of F2}

F2 is a distributor, employees 15 people, and has a turnover of 5 millions EURO per year. This company imports products from the Middle East and resells them to 800 client companies all over Italy and abroad. They have 5 business agents that cover different parts of Italy. This company in Spring 2001 had had an online catalog for four months and already circa 5\% of the business was done through Internet, but with already existing customers. It is possible for the client to log in the company with a password, look at the daily inventories, choose the type of product, the quantity wanted and then submit the order through the web site. They had not seen an increase in the number of clients yet as a consequence of the Home Page.

\subsubsection{Stage I and II}

F2, even though skeptical, adopted e-commerce in 1997 due to the fact that the owner had a friend that convinced him that e-commerce would be very useful for him and to make that investment. Soon F2 realized the benefits of e-commerce and decided to have an online catalog. However, they could just have a static home page providing basic information about the company and the company's products. It was, in fact, too complicated for them to update the catalog on a daily basis as required by their business due to lack of available technologies on the local market such as scanner and digital cameras. Only recently, after they have bought these complementary technologies, it has been possible for them to sell through a WWW catalog, because they can update it on a daily basis by themselves. The company capability level is 3 .

\subsubsection{Stage III}

The main barriers preventing F2 at first from further using e-commerce were lack of complementary technology advances and affordable prices. As the prices of the digital cameras have become more affordable, they have invested also in further capabilities, both technical and human. Examples of human capabilities include training of one person to use the scanner, digital camera and uploading of the pictures into the system, as well as training about how to handle the online catalog. They acknowledge that there are still many of their clients, especially the smaller ones that do not have a computer or at least do not use Internet. We could therefore say that the lack of a critical mass among F2's clients is also another barrier. Among the benefits they have experienced cost savings and timesavings. 


\subsubsection{Stage IV}

F2 also believes that government intervention in terms of awareness creating campaigns, training seminars, and government incentives such as tax-breaks for e-commerce based systems could contribute to an increase in the diffusion of e-commerce among SMEs. They also believe that the accessibility on the local market to complementary technologies such as the scanner and digital camera, the spreading of the English language and the introduction of the EURO could also further the diffusion of e-commerce

\subsection{Description of F3}

The third company (F3) are middlemen in the textile business, doing business mainly with abroad. They import the raw material and export the finished product, produced by local SMEs. They do not have a web site. They are not satisfied with the static web site that is a shopping window. They also showed concern about building a web site giving online access to their product collection because they are afraid that the competitors can copy what they are doing. Therefore they use Internet daily for business-tobusiness operations such as receiving and fulfilling orders, sending digital images of their products, communicating with their clients, and Internet banking. They said that Internet has contributed to increase the number of buyers per each client company they have, with an increase in the final total product sale.

\subsubsection{Stage I and II}

F3 started using e-commerce due to the perceived opportunities and benefits that it could offer them, especially in dealing with international markets. Their technical capabilities in Internet-commerce are however limited to an Internet connection. They are presently using e-commerce for market research, establishing contacts with new potential customers, order taking, order confirmation, sending images of their collection products as attachments after having scanned the products through the scanner, etc. Their capability level is one.

\subsubsection{Stage III}

While experimenting with e-commerce, F3 has realized its barriers and benefits. Among the major barriers they mentioned the lack of critical mass among the suppliers and the buyers, especially those located abroad. They say that many of their clients, especially in the past, did not want to use e- 
commerce because they felt that the security level for conducting web transaction was not sufficient enough. They have been thinking for some time to upgrade their technical system to either build a home page to provide information about the company or even to have an online catalog of their products, however they are afraid of loosing competitive advantage if they put many company information on the web. They are also afraid of setting an online catalog, because they feel that it is not secure enough. Among the benefits they have experienced cost savings and bigger access to international markets.

\subsubsection{Stage IV}

They believe that the main factors that could increase the diffusion of ecommerce are an increase in the security of the WWW system, the spreading of the English language and the introduction of the EURO. They have contacted many companies located abroad, but they cannot really establish any business because they cannot communicate. They were not aware themselves of any government intervention in terms of tax breaks, pilot programs, etc., but they said that they would be willing to experiment with more WWW capabilities if they did not have to make the whole investment by themselves.

\subsection{Description of F4}

F4 is a producer and seller of textiles. The company counts circa 300 employees with a turnover of 15 millions EURO per year. The internal and the external processes are interconnected. They have a home page, but don't have an online catalog because they are worried about the security. The company had started using Internet when none of their clients was using it. They have their own EDB department and do not believe in outsourcing, if Internet has to be used to achieve competitive advantage.

\subsubsection{Stage I and II}

F4 has adopted e-commerce in 1996 as soon as the WWW was introduced. At first they did not know exactly what to use it for, but the owner/CEO had a vision and a belief that it could be used to obtain a competitive advantage. Therefore they started developing some capabilities in e-commerce, both technical and human. They have installed a system that is integrated with Internet, and they have a firewall for protection. In that occasion they also have decided to hire two full time engineers that constitute the EDB department. These engineers are in charge of not only 
maintaining the computer and network systems, but to find always new ways to use both computer systems and e-commerce to decrease costs, increase market share, find new suppliers and customers, etc. F2's production department was completely automated in 1996, and they have automatic sewing and cutting machines, controlled by a computer located at distance. If an error occurs on a machine, most of the times it can be fixed online through the Internet 24 hours per day. F4 is at capability level 2.

\subsubsection{Stage III}

Even though F4 had an Internet connection and had integrated the internal and the external processes, for some years the company could really use e-commerce for just e-mail, market research, etc. as most of their suppliers and clients were not e-commerce adopters. However firmly believing in the technology they were not at all discouraged. Today they use Internet for many purposes, among which order taking, sending invoices, participation to e-auctions, establishing contacts with suppliers of untraditional products or to find lower-cost suppliers. However they do not have an online catalog yet, as they are afraid of loosing control on who is accessing it as they feel the password solution is not secure enough. They use CD-ROM to send the product collection, instead, because in this way they keep control on how many open the CD-ROM.

\subsubsection{Stage IV}

They did not really have any idea about what kind of measures could be taken to improve the diffusion of e-commerce. Having been themselves pioneers, they believe that government intervention in terms of tax incentives, funding, etc. is not really that important. If companies are interested in adopting e-commerce because they can see its advantages, then they believe that they are willing to make the necessary investments. However, they do agree that intervention to spread the use of English is very important. Another factor they considered important is the implementation of EURO.

\subsection{Description of F5}

F5 is a distributor of car parts. They import from all over Italy and distribute and sell to local SMEs, mechanics and private individuals. They have a static home page, but they are planning to make an advanced one with an online catalog of their products in order to sell on Internet. They have been having a permanent Internet connection for the last three years. 
They are mainly using Internet for e-mail, but recently also for sending and receiving orders with suppliers and a subsidiary company located in a nearby city. Their use is limited to 3-5 messages per day. Their capability level is 2 .

\subsubsection{Stage I and II}

F5 got the first Internet connection few years ago, it was a very simple connection and therefore they did not invest much technical or human capabilities in it. Their adoption was mainly due to technology push, that is they were hearing on the television, radio, about this technology and they decided to adopt it. However for circa one year and a half they were not really using e-commerce because they did not know what to do with it.

\subsubsection{Stage III}

Slowly, by trial and error this company has updated its e-commerce capabilities. At first they have been mainly using e-mail, then to receive orders from customers and sending orders to suppliers. Recently they have been using it more actively to search for new suppliers, especially on the international market and to send huge files over Internet with their subsidiary. This was a big saving of personnel resources for them, as they don't need a person to re-key the data with consequent mistakes. They are also considering of putting an online catalog to sell some products on the WWW. However, they are worried about security. The biggest barriers that have prevented them from expanding their e-commerce capabilities have been the difficulties in talking and negotiating with the consultants. They feel very unsecure because different consultants give different solutions, suggestions and prices and cannot really explain them what they can do with the system in simple, understandable terms.

\subsubsection{Stage IV}

They believe that to increase the diffusion of e-commerce it is important that the consultants are better trained to talk with people that are not expert of informatics and to explain in simple terms the potentiality of the system not only from a technical point of view, but also how it can support their business. 


\section{SUMMARY OF RESULTS}

In this paragraph I discuss the factors characterizing each stage of PriceWaterhouseCoopers model found in the case studies. These results are summarized in Table 3.

\subsubsection{Stage I and II}

SMEs might adopt e-commerce due to the potential opportunities or benefits that they perceive this technology can offer as for example to increase competitive advantage (F1, F4, and F3). However, in my study I found that e-commerce adoption can also take place just-by-chance, because the owner of a company has for example a good friend that convince him to adopt e-commerce (F2). Other companies might adopt due to technology push (F5).

\subsubsection{Stage III}

After the decision for primary adoption has been made, the company starts experimenting with e-commerce (secondary adoption), thus realizing benefits, uses and inhibitors.

Uses. Usually SMEs start using e-commerce first mainly as a medium to exchange information (Poon and Swatman, 1999). As the level of awareness, experience and trust in e-commerce increases, SMEs start developing more capabilities and using it for more complicated business-to-business transactions, such as order taking and order confirmation from and to customers, price and inventory inquiries, document exchange and information sharing with buyers, suppliers and partners (e.g. transmission of invoices and images of product samples (F5)). Finally SMEs might be able to establish an online sale presence with an online catalog (F2) and to participate to e-auctions as buyers or sellers (F4) and to do Internet banking (F3) as also Poon (2000) has found. Eventually SMEs would reach external and internal integration (F4, partially F3). Most of the companies in this study are moving from capability level 2 to level 3 and to implementing internal and external integration. The complexity of a company's ecommerce capabilities is therefore a function of the level of awareness, trust and experience the SME has with this technology.

Barriers. As pointed out in other studies, also this study has showed that lack of competence, knowledge and awareness of the technology and its potentials is an important barrier to the adoption and diffusion of ecommerce among SMEs (Poon and Swatman, 1997). Internal resistance to 
change (F4) or implementation gap is also another important barrier. Poor communication between the IS consultants or IT specialists and the SMEs is

\begin{tabular}{|c|c|}
\hline $\begin{array}{l}\text { Stages of the } \\
\text { PriceWaterhouseCoopers model of } \\
\text { SMEs E-commerce Adoption }\end{array}$ & $\begin{array}{l}\text { Factors characterizing the stages found in the } \\
\text { empirical investigation }\end{array}$ \\
\hline Stage I & $\begin{array}{l}\text { Adoption Reasons: Perception of Opportunities } \\
\text { and Benefits; Just-By-Chance (JBC); Vision of } \\
\text { Getting a Competitive Advantage; Technology } \\
\text { Push }\end{array}$ \\
\hline Stage II & $\begin{array}{l}\text { E-commerce Capabilities: Level 1-F3; Level 2: F1, } \\
\text { F4, F5; Level 3:F2. }\end{array}$ \\
\hline Stage III & $\begin{array}{l}\text { Uses: Communication; Order Taking and Order } \\
\text { Confirmation From and To Customers; Send } \\
\text { Purchase Orders to Suppliers; Price and Inventory } \\
\text { Inquiries; Document Exchange and Information } \\
\text { Sharing with Buyers, Suppliers and Partners (E.g. } \\
\text { Transmission of Invoices and Images of Product } \\
\text { Samples); Market Research; Online Sale Presence; } \\
\text { Participation to E-Auctions as Buyers or Sellers; } \\
\text { Finding and Establishing Contacts with Suppliers } \\
\text { or Partners; Internet Banking; Internal and } \\
\text { External Integration }\end{array}$ \\
\hline Stage III & $\begin{array}{l}\text { Adoption Barriers: Lack of Competence, } \\
\text { Knowledge and Awareness of the Technology and } \\
\text { its Potentials; Internal Resistance to Change or } \\
\text { Implementation Gap; Lack of Critical Mass of } \\
\text { Suppliers, Customers and Partners Using Internet; } \\
\text { Poor Communication Between SMEs and IS } \\
\text { Specialists; An Online Sale Presence Might } \\
\text { Decrease SMEs Competitive Advantage; Lack of } \\
\text { Trust in E-commerce }\end{array}$ \\
\hline Stage III & $\begin{array}{l}\text { E-commerce Benefits: Contribution to } \\
\text { internationalization; Increased Efficiency and } \\
\text { Easiness to Do Business; Time Savings; Improved } \\
\text { Communication Around the Clock; Administrative } \\
\text { Cost Savings (Fax, telephone, postal service, } \\
\text { paper); Increased Company Visibility; Increased } \\
\text { Market Potential }\end{array}$ \\
\hline Stage IV & $\begin{array}{l}\text { Measures: Diffusion of Complementary Factors } \\
\text { Adding Value to E-commerce (e.g. technologies } \\
\text { such as digital image technologies, EURO and } \\
\text { spreading of English) } \\
\text { Government Intervention and Public } \\
\text { Administration as User. }\end{array}$ \\
\hline
\end{tabular}

Table 3. Factors Characterizing the Stages of the Adoption of B-to-B E-commerce Emerged in the Case Studies 
another important inhibitor as the consultants are not able to explain in simple terms what Internet can be used for (F1, F3, F5). SMEs fear that putting the product portfolio on Internet might decrease their competitiveness by giving away to competitors useful information (F3, F4). Lack of critical mass of suppliers, buyers and partners using e-commerce is also an important inhibitor. The critical mass has been lacking over the last years, but recently it is getting better.

Benefits. Benefits are the advantages that SMEs experience or expect to gain from the adoption of e-commerce. Improved communication around the clock, administrative cost savings, and increased efficiency and easiness to do business are the most important short-term benefits. Increased company visibility, market potential, and a contribution to internationalization are among the most important long-term indirect benefits (Poon and Swatman, 1999).

\subsubsection{Stage IV}

As SMEs experience with e-commerce, they also get an understanding of what kind of intervention should be taken to increase its diffusion and the business value that the adoption of e-commerce can bring to a small enterprise. This study's empirical investigation has found that the government and public administration are very important actors in promoting the diffusion of e-commerce. This can be achieved among others by promoting e-commerce use, raising awareness of e-commerce through informational campaigns, increase the quantity and quality of government services on the Internet especially by the local public administration.

Barua, Lee and Whinston (1996) develop a business value complementarity theory where the main idea is the construction of a multilevel model where the highest level variable is the dependent variable, the same that has to be optimized. The variables at the other levels are the independent variables. According to Barua et al. (1996) the exploration of complementarity among the independent variables could contribute to an increase in the value of the dependent variable. Milgrom and Roberts (1990) define two activities to be complementary if the profit or value created by doing both at the same time is greater then the sum of the individual profits from doing just one or the other.

If we use the business value modeling logic of Barua et al. (1996), then we can represent the variables that have to be optimized and the independent variables as in fig. 2. This figure means that in order to optimize the business value that e-commerce brings to a corporation it is important to explore the synergies among the complementary factors representing the independent variables of the model. 


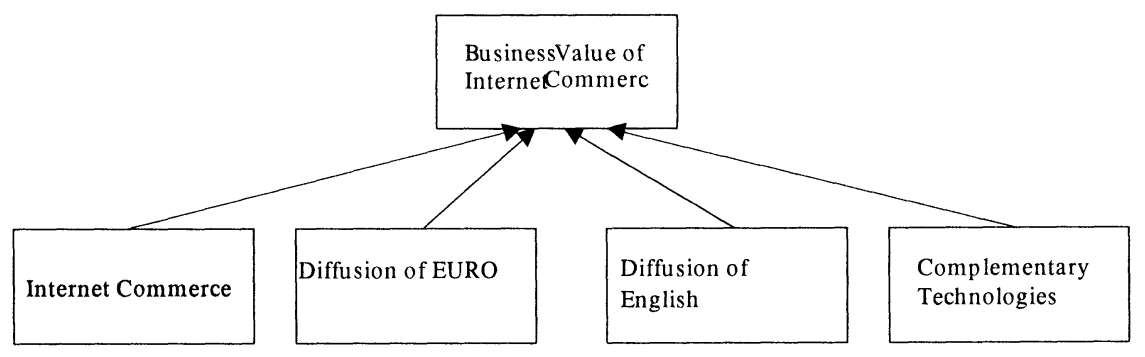

Figure 2. Business value compementarity model of e-commerce to SMEs

This empirical investigation has showed that complementary factors that could contribute to an increase in the business value of e-commerce to a small enterprise, especially regarding competitive advantage and internationalization, are the diffusion of complementary technologies such as digital imaging (F2), the implementation of the EURO (F2, F3, F4) and the diffusion of English as the common business language (F1, F2, F3, F4, F5).

\section{CONCLUSIONS}

It can be concluded that PriceWaterhouseCoopers model fits the data only partially. For example the first stage of the model takes into consideration only the opportunities and benefits that motivate SMEs for primary adoption of e-commerce, but it does not take into consideration other factors such as technology push and those situations that can fit under the category just by chance. Furthermore, regarding capabilities the model takes into consideration only the level of sophistication of the home page. With level one representing a company with no web capabilities and level four a sophisticated web site, where it is possible to order through an online catalog and to pay online for the products bought on Internet.

The model does not take into consideration, however, the company's capabilities that have to be either developed in house or acquired on the market to go from one stage to the next of web site development. These are also the problems that usually characterize the assimilation gap. The model also does not take into consideration the changes in the business processes that are required as a consequence of increasing the sophistication level of the home page, if e-commerce has to be conducted successfully.

These limitations can be however issues for further research. For example the model could be expanded with the capabilities, both technical and human that a company needs as a consequence of the evolution of the 
home page, as well as the required changes in the business processes. To do this, many more in depth case studies are necessary, as the empirical data on the basis of which these conclusions have been drawn are presently very limited.

\section{REFERENCES}

Barua A., Lee, S. C.H., Whinston A.B. (1996), 'The Calculus of Reengineering', Information Systems Research, Vol. 7, No. 4, pp. 409-428.

Bickerton, P., Bickerton, M, Simpson-Holley, K. (1999), Cyberstrategy: Business Strategy for Extranets, Intranets and the Internet, The Chartered Institute of Marketing, Oxford, United Kingdom.

Damsgaard J., Scheepers, R.' Power, Influence and Intranet Implementation, A Safari of South African Organizations', Information Technology and People, Vol. 12, No. 4, 1999

Gallivan, M.J (2001), 'Organizational adoption and assimilation of complex technological

innovations: Development and application of a new framework', Database for Advances in Information Systems, Vol. 32, No. 3, pp. 51-85.

Grant, S. (1999) E-commerce for small businesses, in 'Proceedings of the 2nd International conference IeC '99', Manchester, November 1-3, 1999, pp. 65-72.

Milgrom, P., Roberts, J. (1992), Economics, Organization and Management, New York, Prentice Hall.

Nolan, R.L. (1973) 'Managing the Computer Resource: A Stage Hypothesis',

Communications of the ACM, 16, 399-405.

OECD (1999), 'Business-to-Business E-commerce: Status, Economic Impact and Policy Implications', OECD Working Paper, NO. 77.

Poon, S., (2000), Business Environment and E-commerce Benefit-A Small Business Perspective, European Journal of Information Systems, Vol. 9, pp. 72-81.

Poon, S., Swatman, P. (1997) Small Business Use of the Internet: Findings from the Australian Case Studies. International Marketing Review, Vol. 14, No. 5.

Poon, S., Swatman, P. (1999) An Exploratory Study of Small Business E-commerce Issues, Information and Management, 35 (1999) pp. 9-18.

Prescott, M.B., and Conger, S.A. (1995). "Information Technology Innovations: A Classification by IT Locus of Impact and Research Approach," The DATABASE for Advances in Information Systems, Vol. 26, Nos. 2/3, pp. 20-41.

PriceWaterhouseCoopers (1999), SME E-commerce Study, Asia Pacific Economic Cooperation (APEC), Final Report, September 24.

Quelch, J. A., Klein, L. R. (1996), 'The Internet and International Marketing', Sloan Management Review, Spring, pp.60-75.

Rogers, E.M., (1995), The Diffusion of Innovations, 4th edition. Free Press, New York.

Zaltman, G., Duncan, R., and Holbeck, J.(1973). Innovations and Organizations,

New York: Wiley \& Sons.

Zwass, V. (1997), Foundations of Information Systems, New York, McGraw-Hill.

Yin, R.K.; Case Study Research Design and Methods, Second Edition, Vol. 5, Sage Publications, 1994. 